\title{
The Relationship between Father Involvement and Dating Violence in Middle Adolescent
}

\author{
Maya Damayanti ${ }^{1}$, Efriyani Djuwita ${ }^{2 *}$ \\ 1,2. Faculty of Psychology, Depok, Indonesia \\ *E-mail: efriyani.dj@gmail.com
}

\begin{abstract}
Dating violence is a form of aggressive behavior that is often shown as a form of problemsolving by adolescents when they conflict with their partner. However, such behavior can be prevented by parent involvement role, such as father involvement. Past studies have suggested that father involvement was significantly associated with the decline in children problem behavior in general. The current correlation study was conducted to examine the relationship between father involvement and dating violence in middle adolescence. Father involvement was measured using Father Involvement Scale and Dating violence behavior was measured using The Revised Conflict Tactics Scale. The participants of this study were 354 adolescents aged 14 -18 years. The result showed that both behavioral $(r=-0.095 ; p<0.05)$ and affective domain of father involvement $(r=-0.152 ; p<0.01)$ were negatively correlated with dating violence behavior in middle adolescents, suggesting that the more involved the father was, the lower the dating violence behavior shown by middle adolescents. The implication of these findings on father-child relationship and the rate of aggressive and violence behavior is discussed.
\end{abstract}

Keywords: dating violence; father involvement; middle adolescence; romantic relationship

\section{Introduction}

Aggressive behavior can occur when an individual experience an emotional state, usually anger, that continues the desire to vent the emotion in a particular form or object (Sarwono \& Meinarno, 2006). There are two forms of aggressions that can be shown by adolescents: (1) aggressiveness which involves physical and verbal acts, such as hitting, pushing, mocking, and threatening; (2) aggressiveness that contains manipulation in a relationship and is aimed to hurt others, such as sabotage in friendship and violent behavior in a dating relationship (Card, Sawalani, Stucky, \& Little, 2008).

Aggressive behavior in dating violence can appear as a way to solve problems in a romantic relationship. Research by Connoly, Craig, Goldberg, and Pepler (2004) showed that about $20-50 \%$ of adolescents had experienced aggressive behavior of their partners during dating. One of the phenomena that can illustrate the violence that occurred during dating was the case of a man called FA who committed violence during a date with NN (Hamdi,
2017). During the dating, it was known that the FA often intimidated $\mathrm{NN}$ by pinching, hitting, even pounding NN while having a fight or when NN would not obey what FA wanted. In addition to physical violence, FA was also known to have forced $\mathrm{NN}$ to have sexual intercourse and threatened $\mathrm{NN}$ by continuously calling $\mathrm{NN}$.

Some studies have suggested that dating violence may include physical violence such as hitting, sexual violence such as forced sex, and psychological violence such as insulting a partner (Straus, Hamby, McCoy, \& Sugarman, 1996; CDC, 2016). Unlike physical violence, psychological violence is often not taken too seriously by the perpetrator, the victim or the environment. It happens because psychological violence is usually misinterpreted as a joke or protection for the victim. This type of violence is also often overlooked by the environment because there is no physical evidence of the violence that occurred.

According to Bethke and Dejoy (1993), dating violence can occur in adolescents due to the lack of dating experience and lack of understanding about 
what they can or cannot do to their partner. Moreover, violence toward partner can be done because of the sense of belonging to their partner (DeGenova \& Rice, 2005), which may make the perpetrators feel that they are free to do anything to their partner.

The occurrence of dating violence can also be influenced by a number of factors such as peers, drug use, poor problem-solving skills, and exposure to the aggressive behavior of parent-child relationships (The Riggs, \& O'Leary, in Luthra, \& Gidycz, 2006; Fergusson, Swain-Campbell, \& Horwood, in Miller, et al, 2009). There are two important domains in parenting which are associated with the emergence of aggressive behavior in children. Those important domains are parental beliefs and attitudes as well as parent involvement (Baumrind (1991); Maccoby \& Martin (1983)).

Parental beliefs and attitudes can be explained as the expressions of values, thoughts, beliefs, and considerations used in parenting. While, parent involvement can be explained as for how much parent's involvement in the development of emotional, social, home environment and school environment of their child (Hamner, Latzman, Chan, 2015; Holden \& Buck, in Shaheen, 2015). Some studies explain that the form of parent involvement such as monitoring children's activities regularly can reduce children aggressive behavior. It is also explained that parents who help adolescents to develop their self-worth can reduce the possibility of adolescents becoming involved in an abusive relationship (Baumrind; Maccoby \& Martin, in Miller et al, 2009; Cleveland, Herrera, and Stuewig, in Green, et al., 2014)

From the explanations that have been described previously, it appears that the parent involvement in their children development is very important. In practice, there are the differences between mother and father involvement in childhood development. According to Thompson and Walker (in Han \& Jun, 2013), men and women tend to have different ways of parenting after they get married. Mothers are said to have more primary roles and responsibilities in providing emotional support, parenting, establishing rules and organizing child activities such as academic, social and friendship activities. While father involvement is more visible in financial fulfillment, discipline, independence, career, and encourage children to fulfill their responsibilities (Han \& Jun, 2013).
But Finley and Schwartz (2004) argue that father involvement is not only seen from the aspects of behavior mentioned above but also seen from the children affection needs fulfillment such as the warmth of the relationship between children and fathers. It is said that fathers who build positive relationships can create the feelings of being loved and being secured for children so it makes them behave better (American Academy of Pediatrics, 1998). Furthermore, the time spent by fathers can also affect children behaviors. Some research said that father who has time to provide emotional support like discussing problems and giving advice or guidance for problem-solving could reduce behavioral problems such as aggressive behavior in children (Bronte-Tinkew, Moore, \& Carrano, 2006; Harris, Furstenberg, Marble, 1998).

Currently, there have been a lot of studies about father involvement in children development in Indonesia. It shows that researchers want to increase public knowledge and awareness about the importance of father involvement. Unfortunately, there are not many father involvement researches focusing on adolescents. One of many research about the relationship between father involvement and aggressive behavior have already been conducted, but until now there has been no specific research to discuss the relationship between father involvement and aggressive behavior in the form of dating violence.

In fact, dating violence in adolescence is said to be the foundation of the aggressive and violent behavior in the romantic relationships when they become adults (Capaldi \& Gorman-Smith, in Miller et al., 2009). Linder, Crick, and Collins (2002) revealed that the quality of a romantic relationship would decrease when individuals use violence. Some impacts that may occur are having less or little trust towards their partner, the feeling of frustration, and dissatisfaction towards the relationship. Therefore, researchers of this study are interested to see whether there is a relation between father involvement and dating violence among adolescents so it can help them to increase their romantic relationship quality in the future.

\section{Methods}

Sample. Participants in this study were 354 adolescents (247 women and 107 men) aged $14-18$ years old from Jabodetabek, currently in a dating relationship, and have a living father as biological or step-father. 
Research Design. The current study is retrospective and correlational. This study aimed to examine the relationship between two variables: father involvement and dating violence behavior.

Instrument and Measurement. Father involvement. Nurturant Fathering Scale (NFS) and Father Involvement Scale (FIS) by Finley and Schwartz (2004) were used to assess father involvement. Nurturant Fathering Scale (NFS) measures the affective quality of the relationship between father and child. NFS has nine items that are measured on a 5-point Likert-type scale $(1=$ "never involved", 5 = "always involved"). Some examples of the items are: "how much do you think your father enjoyed being father?", "did your father have enough energy to meet your needs?", and "overall, how would you rate your father?". NFS score ranges from 9 to 45 . Moreover, FIS consists of two sub-scales which are: the reported father involvement scale and the desired father involvement scale. In this study, researchers only used a reported father involvement scale (FIS Reported) because the researchers only wanted to know about the child's perception of father's involvement during their development. The reported father involvement scale (FIS) consists of 20 items showing 20 domains of the child's life, that are measured on a 5-point Likert-type scale $(1=$ "never involved", five = "always involved") FIS score ranges from 20 to 100 . The total score indicates to what extent the father is involved in every aspect of the child's life during their development. The reliability index for the reported-FIS and the NIS is .912 and .860 , respectively.

Dating violence. The Revised Conflict Tactics Scale (CTS2) by Straus, Hamby, McCoy, and Sugarman (1996) was used to measure the extent to which the partner (dating, cohabiting, and marriage) experienced violence both physically, psychologically and sexually as problem-solving in the relationships they intertwined from the beginning. In this study, only three of the five dimensions in the CTS2 were used in this study, i.e., the Physical Assaults, Psychological Aggression, and Sexual Coercion. Furthermore, only the appearance of violent behavior committed by the perpetrator was measured and therefore only relevant items were used. This was done because this study focuses on the perpetrator. The three dimensions in CTS2 were measured on a 5-point Likert-type scale $(0=$ "never", 4 = "very often"). Of the total 27 items, eight items were from the psychological aggression dimension, 12 items were from the physical assault dimension, and seven items were from the sexual coercion dimension. Some examples of the items: "I insulted or swore at my partner" for psychological aggression, "I threw something at my partner that could hurt" for physical assault, and "I used threats to make my partner have sex" for sexual coercion. The reliability index of CTS2 was.844.

Procedure. The questionnaires were distributed in print and via online media

Data Analyses. Initially, there were 390 participants; however, those who did not meet the participants' inclusion criteria for the study and those who extremely deviated from the average $(> \pm$ $3 S D$ ). Statistical analyses were conducted on the remaining participants using, and Pearson correlation to determine the magnitude and direction of the relationship between the two variables. All statistical analyses were done using Statistical Packages for Social Science (SPSS) version 20.

\section{Results}

Of the total 354 adolescents aged 14 to 18 years participated in this study, $74.6 \%$ were completed the online questionnaires while the remaining $25.4 \%$ completed the printed version. Participants' demographic data, i.e., sex, age, domicile, duration of the dating relationship, father status, father's age, and father's job, can be seen in Table 1 .

The result of the analysis was obtained after finding correlation of total score from each measuring instrument by using Pearson Correlation on SPSS program

Pearson correlation analyses showed that there was a significant negative relationship between father involvement and dating violence. The behavioral domain of father involvement (i.e., reported-FIS) was negatively correlated with dating violence $(r=-$ $0.095, p=.037$. Similarly, the affective domain of father involvement (NIS) was also negatively correlated with dating violence $(r=-0.152 ; p=$ $.002)$. The coefficient of determination $\left(\mathrm{r}^{2}\right)$ value for the relationship between behavioral domain of father involvement (reported FIS) and dating violence was.009, suggesting a small effect size.

Moreover, the coefficient of determination $\left(\mathrm{r}^{2}\right)$ value for the relationship between affective domain of father involvement (NIS) and dating violence was .023 , suggesting a small effect size. 
Table 1.

Demographic characteristic of participants and their father

\begin{tabular}{|c|c|c|}
\hline Variables & Total & Percentage \\
\hline \multicolumn{3}{|l|}{ Gender } \\
\hline Women & 247 & $69.8 \%$ \\
\hline Men & 107 & $30.2 \%$ \\
\hline \multicolumn{3}{|l|}{ Age } \\
\hline 14 years. & 1 & $0.3 \%$ \\
\hline 15 years. & 36 & $10.2 \%$ \\
\hline 16 years & 94 & $26.6 \%$ \\
\hline 17 years & 115 & $32.5 \%$ \\
\hline 18 years. & 108 & $30.5 \%$ \\
\hline \multicolumn{3}{|l|}{ Domicile } \\
\hline Jakarta & 176 & $49.7 \%$ \\
\hline Bogor & 29 & $8.2 \%$ \\
\hline Depok & 79 & $22.3 \%$ \\
\hline Tangerang & 14 & $4.0 \%$ \\
\hline Bekasi & 56 & $15.8 \%$ \\
\hline \multicolumn{3}{|l|}{ Duration of relationship } \\
\hline $0-6$ Months & 131 & $37.1 \%$ \\
\hline $7-12$ Months & 74 & $20.9 \%$ \\
\hline$>1$ Years & 149 & $42.0 \%$ \\
\hline \multicolumn{3}{|l|}{ Father's status } \\
\hline Biological Father & 348 & $98.3 \%$ \\
\hline Stepfather & 6 & $1.7 \%$ \\
\hline \multicolumn{3}{|l|}{ Father's age } \\
\hline $30-40$ y.o. & 22 & $6.2 \%$ \\
\hline $41-50$ у.о. & 189 & $53.4 \%$ \\
\hline $51-60$ у.о. & 117 & $33.1 \%$ \\
\hline$>60$ у.о. & 15 & $4.2 \%$ \\
\hline Do not know & 11 & $3.1 \%$ \\
\hline \multicolumn{3}{|l|}{ Father's Job } \\
\hline Private employees & 112 & $31.7 \%$ \\
\hline Pensionary & 16 & $4.5 \%$ \\
\hline Government employees & 35 & $9.9 \%$ \\
\hline Army & 10 & $2.8 \%$ \\
\hline Entrepreneur & 82 & $23.2 \%$ \\
\hline Others & 79 & $22.3 \%$ \\
\hline Do not know & 20 & $5.6 \%$ \\
\hline
\end{tabular}

\section{Discussion \& Conclusion}

Discussion. The current study aimed to examine the relationship between father involvement and dating violence in middle adolescents. In line with the hypothesis, the father involvement (both behavioral and affective domain) were negatively correlated with dating violence, that is, the higher the father involvement score is, the lower dating violence was in middle adolescents. The findings of this study support the findings of previous research. Bronte-
Tinkew, Moore, and Carrano (2006) found that positive relationship between father and child can decrease the possibility of the emergence of children behavioral problems in general. In addition, Carlson (2006) found that father involvement was significantly associated with the decline in children problem behavior in general. In this study, the researchers asked participants to think about whether he or she ever committed violence to his/her romantic partner during their dating period, but researchers did not determine the time span of dating violence. Suggestions for further research, it is better to determine the time span, for example, the last one or three months so that the participants can recall recent violent behaviors better. and provide more accurate responses. The advantage of this study is that it contributes to the lacking number of studies examining the relationship between father involvement and dating violence. Research on father involvement is usually associated with aggressive behaviors directed to friends, to parents, as well as to foreigners (Flouri, 2002, Marcus, 2007).

Conclusions. The results obtained from this study is that there is a significant negative relationship between father involvement and dating violence in middle adolescents. Based on the conclusion above, it can be said that the higher father involvement, the lower dating violence in middle adolescents or vice versa,

\section{References}

Allen, S., \& Daly, K. (2007). The Effects of Father Involvement: An Updated Research Summary of the Evidence. Guelph: University of Guelph.

American Academy of Pediatrics. (1998). Guidance for Effective Discipline. Pediatrics, 101(4), 723 - 728

Baumrind, D. (1991). The influence of parenting style on adolescent competence and substance use. Journal of Early Adolescence, 11, 56-95.

Bethke, T., \& DeJoy, D. (1993). An experimental study of factors influencing the acceptability of dating violence. Journal of Interpersonal Violence, 8, 36-51.

Bronte-Tinkew, J., Moore, K. A., \& Carrano J. (2006). The Father-Child Relationship, Parenting Styles, and Adolescent Risk Behaviors in Intact Families. Journal of Family Issues, 27(6), 850 - 881

Card, N. A., Sawalani, G. M., Stucky, B. D., \& Little, T. D. (2008). Direct and Indirect Aggression During Childhood and Adolescence: A Meta-Analytic Review of Gender Differences, Intercorrelations, and Relations to Maladjustment. Child Development, 79 (5), 1185 - 1229.

Carlson, M. J. (2006). Family Structure, Father Involvement, and Adolescent Behavioral Outcomes. Journal of Marriage and Family, 68, 137 - 154 
CDC. (2007). Dating violence and Sexual Violence Victimization Assessment Instruments for Use in Healthcare Settings. GA: Centers for Disease Control and Prevention, National Center for Injury Prevention and Control.

CDC. (2015). Dating violence Surveillance: Uniform Definitions And Recommended Data Elements. Atlanta: National Center for Injury Prevention and Control.

CDC. (2016). Understanding Teen Dating Violence. National Center for Injury Prevention and Control. Division of Violence Prevention.

Connoly, J., Craig, W., Goldberg, A., \& Pepler, D. (2004). Mixed-Gender Groups, Dating, and Romantic Relationship in Early Adolescence. JOURNAL OF RESEARCH ON ADOLESCENCE, 14(2), 185 - 207.

DeGenova, M. K., \& Rice, F. C. (2005). Intimate Relationships, Marriages, and Families. New York: McGraw-Hill.

Dutton, D. G. (2007). The Abusive Personality: Violence and Control in Intimate Relationships. New York: The Guilford Press.

Finley, G. E., \& Schwartz, S. J. (2004). The Father Involvement and Nurturant Fathering Scales: Retrospective Measure for Adolescent and Adult Children. Educational and Psychological Measurement, 64(1), 143-164.

Flouri, E., \& Buchanan, A. (2002). Life Satisfaction in Teenage Boys: The Moderating Role of Father Involvement and Bullying. Aggressive Behavior, 28, 126 - 133.

Gravetter, F. J., \& Forzano, L.-A. B. (2012). Research Methods for the Behavioral Sciences. Wadsworth: Wadsworth Cengage Learning.

Gravetter, F. J., \& Wallnau, L. B. (2007). Statistics for the behavioral sciences. Australia: Thomson/Wadsworth.

Green, B. A., Davis, C. G., Clark, T. T., Quinn, C. R., \& Coupet, Q. R. (2014). Father Involvement, Dating Violence, and Sexual Risk Behaviors Among a National Sample of Adolescent Females. Journal of Interpersonal Violence, 1 - 21.

Hamdi, I. (2017). Penyekapan Mantan Pacar, Febi Sering Memukuli NN. Metro Tempo.Co. Diakses pada tanggal 5 Juni 2017 dari https://metro.tempo.co/read/news/2017/06/04/064881371/p enyekapan-mantan-pacar-febi-sering-memukuli-nn

Hamner, T., Latzman, R. D., \& Chan W. Y. (2015). Exposure to Community Violence, Parental Involvement, and Aggression Among Immigrant Adolescents. J Child Fam Stud.
Han, Y. S., \& Jun, W. P. (2013). Parental Involvement in Child's Development: Father vs. Mother. Open Journal of Medical Psychology, 2, 1 - 6

Harris, K. M., Furstenberg, F. F., \& Marmer, J. K. (1998). Paternal Involvement with Adolescents in Intact Families: The Influence of Fathers Over the Life Course. Demography, 35(2), 201 - 216.

Kumar, R. (2011). Research Methodology: a step-by-step guide for beginners. London: SAGE Publications Ltd.

Lamb, M. E., Pleck, J. H., Charnov, E. L., \& Levine, J. A. (1987). A biosocial perspective on paternal behavior and involvement. In Biosocial Perspectives and Parental Investment (pp. 111-142). Hawthorne, NY: Aldine.

Lewis, S. F., \& Fremouw, W. (2001). Dating Violence: A Critical Review of the Literature. Clinical Psychology Review, 21(1), 105 - 127.

Linder, J. R., Crick, N. R., \& Collins, W. A. (2002). Relational Aggression and Victimization in Young Adults' Romantic Relationship: Associations with Perceptions of Parent, Peer, and Romantic Relationship Quality. Oxford: Blackwell Publishers.

Luthra, R., \& Gidycz, C. a. (2006). Dating Violence Among College Men and Women: Evaluation of a Theoretical Model. Journal of Interpersonal Violence, 21(6), 717 . 731.

Maccoby, E. A., \& Martin, J. A. (1983). Socialization in the context of the family: Parent-child interaction. In P. H. Mussen (Ed.), Handbook of child psychology, 4(4), 1101.New York: Wiley.

Marcus, R. F. (2007). Aggression and Violence in Adolescence. Cambridge: Cambridge University Press

Mitchell, C., \& Anglin, D. (2009). Dating violence: A HealthBased Perspective. New York: Oxford University Press, Inc.

Sarwono, S. W., \& Meinarno, E. A. (2006). Psikologi remaja (Edisi revisi). Jakarta: Rajawali

Shaheen, F. (2015). Role of Parental Attitude in Development of Aggressive Behavior among Adolescents. The International Journal of Indian Psychology, 2(3), 36-48.

Simons, R. L., Lin, K., \& Gordon, L. C. (1998). Socialization in the Family of Origin and Male Dating Violence: A Prospective Study. Journal of Marriage and the Family, 60, 467 - 478

Straus, M. A., Hamby, S. L., McCoy, S. B., \& Sugarman, D. B. (1996). The Revised Conflict Tactics Scales (CTS2) Development and Preliminary Psychometric Data. Journal of Family Issues, 17(3), 283 - 316. 